\title{
Using high-resolution melting to identify Calliphoridae (blowflies) species from Brazil
}

\author{
Pablo Viana Oliveira ${ }^{\text {Corresp., }}{ }^{1}$, Francine Alves Nogueira de Almeida ${ }^{1}$, Magda Delorence Lugon ${ }^{1}$, Karolinni Bianchi \\ Britto $^{1}$, Janyra Oliveira-Costa ${ }^{2}$, Alexandre Rosa dos Santos ${ }^{3}$, Greiciane Gaburro Paneto ${ }^{1,4}$ \\ 1 Programa de Pós-Graduação em Biotecnologia, Universidade Federal do Espírito Santo, Vitória, Espírito Santo, Brazil \\ 2 Polícia Civil do Estado do Rio de Janeiro, Instituto Médico Legal Afrânio Peixoto, Rio de Janeiro, Rio de Janeiro, Brazil \\ 3 Centro de Ciências Agrárias e Engenharias, Universidade Federal do Espírito Santo, Alegre, Espírito Santo, Brazil \\ 4 Centro de Ciências Exatas, Naturais e da Saúde, Universidade Federal do Espírito Santo, Alegre, Espírito Santo, Brazil \\ Corresponding Author: Pablo Viana Oliveira \\ Email address: pablo.viana27@gmail.com
}

Forensic entomology is the study of insects and other arthropods used in the solution of crimes. Most of entomological evidences strongly depend on accurate species identification. Therefore, new methods are being developed due to difficulties in morphological identification, including molecular methods such as High-Resolution Melting. In this study, we reported a new HRM primer set to identify forensically important Calliphoridae (blowflies) from Brazil. For such purpose, Calliphoridae species of forensic importance in Brazil were listed and confirmed by specialists. Mitochondrial COI sequences of those species were downloaded from databases and aligned, and polymorphic variations were selected for distinction between species. Based on it, HRM primers were designed. Forty-three fly samples representing six species were tested in the HRM assay. All samples had the COI gene sequenced to validate the result. Identifying and differentiating the six species proposed using a combination of two amplicons was possible. The protocol was effective even for old insect specimens, collected and preserved dried for more than ten years, unlike the DNA sequencing technique that failed for those samples. The HRM technique proved to be an alternative tool to DNA sequencing, with advantage of amplifying degraded samples and being fast and cheaper than the sequencing technique. 
1 Using High-Resolution Melting to identify Calliphoridae (blowflies) species

4 Pablo Viana Oliveira ${ }^{1}$, Francine Alves Nogueira de Almeida ${ }^{1}$, Magda Delorence Lugon ${ }^{1}$, 5 Karolinni Bianchi Britto ${ }^{1}$, Janyra Oliveira-Costa ${ }^{2}$, Alexandre Rosa dos Santos ${ }^{3}$, Greiciane 6 Gaburro Paneto ${ }^{1,4}$

8 1. Programa de Pós-Graduação em Biotecnologia, Universidade Federal do Espírito Santo, Vitória, Espírito Santo, Brazil

9 2. Polícia Civil do Estado do Rio de Janeiro, Instituto Médico Legal Afrânio Peixoto, Rio de Janeiro, Rio de Janeiro, 10 Brazil

11 3. Centro de Ciências Agrárias e Engenharias, Universidade Federal do Espírito Santo, Alegre, Espírito Santo, Brazil

12 4. Centro de Ciências Exatas, Naturais e da Saúde, Universidade Federal do Espírito Santo, Alegre, Espírito Santo, Brazil 13

15 Corresponding Author: Pablo Viana Oliveira

16 Email address: pablo.viana27@gmail.com 
17 Using High-Resolution Melting to identify Calliphoridae (blowflies) species from Brazil

18

19

20

21

22

23

24

25

\section{ABSTRACT}

Forensic entomology is the study of insects and other arthropods used in the solution of crimes. Most of entomological evidences strongly depend on accurate species identification. Therefore, new methods are being developed due to difficulties in morphological identification, including molecular methods such as High-Resolution Melting. In this study, we reported a new HRM primer set to identify forensically important Calliphoridae (blowflies) from Brazil. For such purpose, Calliphoridae species of forensic importance in Brazil were listed and confirmed by specialists. Mitochondrial COI sequences of those species were downloaded from databases and aligned, and polymorphic variations were selected for distinction between species. Based on it, HRM primers were designed. Forty-three fly samples representing six species were tested in the HRM assay. All samples had the COI gene sequenced to validate the result. Identifying and differentiating the six species proposed using a combination of two amplicons was possible. The protocol was effective even for old insect specimens, collected and preserved dried for more than ten years, unlike the DNA sequencing technique that failed for those samples. The HRM technique proved to be an alternative tool to DNA sequencing, with advantage of amplifying degraded samples and being fast and cheaper than the sequencing technique.

KEYWORDS: forensic entomology, species identification, DNA Barcoding, BOLD, melting curves. 


\section{INTRODUCTION}

Morphology-based species identification, although widely used, may be difficult in cases of closely related species and damaged or degraded specimens (Galan et al. 2012; Sontigun et al. 2018), and due to the lack of taxonomic keys and specialists (Chen et al. 2004; Hebert et al. 2003b). Technologies, such as scanning electron microscopy (SEM), can help giving detailed information on the external morphological characteristics of the body and genitalia of adult blowflies and can help identify the immature forms (David et al. 2008; Mendonça et al. 2014a, 2014b; Sontigun et al. 2018). The destruction of these characteristics, however, may lead to incorrect identification or non-identification (GilArriortua et al. 2014).

DNA Barcoding, a powerful molecular tool, was created to overcome these barriers. Based on one or more standardized DNA regions - the mitochondrial Cytochrome Oxidase I gene (COI) in the case of animals (Hebert et al. 2003a), and chloroplastidial and nuclear regions for plants (CBOL Plant Working Group et al. 2009; Kress et al. 2005) and fungi (Schoch et al. 2012) - Barcoding allows identifying the species with enough accuracy and is applicable to many areas such as tracking of adulterations in food (Dawnay et al. 2016), beverages (Castro et al. 2017), medicinal herbs (Bansal et al. 2018), identification of flies in forensic area (Jang et al. 2019; Oliveira et al. 2017; Rolo et al. 2013) and species that cannot be determined morphologically (Klippel et al. 2015), among others.

Insect specimens are used to estimate the post-mortem interval (PMI) in forensic entomology, which comprises the time from death to the discovery of the human corpse. It is based on the life cycle stage and the succession patterns of insects (Amendt et al. 2004; Catts \& Goff 1992). Furthermore, these insects are used to determine the cause of the death or whether the 
60 body was transported to a place other than that of death (Amendt et al. 2011; Zajac et al.

61 2016). The blowflies of family Calliphoridae (Insecta, Diptera) colonize the corpse before the

62 other insects and provide most of the information about the PMI (Cooke et al. 2019). Families

63 such as Muscidae, Sarcophagidae, Fanniidae and Phoridae are also forensically important,

64 besides other insects of orders Coleoptera, the beetles, Hymenoptera, the wasps, ants and bees, 65 and Lepidoptera, the butterflies (Amendt et al. 2004).

66 Usually, DNA barcoding technique uses fresh or preserved tissue samples to extract DNA

67 since long amplicons are necessary (658 bp for COI, for example). However, in many 68 circumstances, recovering sequences is not possible because only degraded DNA is available 69 (Boyer et al. 2012), which is the major problem of specimens older than a decade (Hajibabaei et al. 2006). The High-Resolution Melting (HRM) analysis is an alternative method to 71 sequencing to overcome this problem (Fernandes et al. 2017; Osathanunkul et al. 2018). This is a RT-PCR-based and non-contaminated post-PCR technique that allows analyzing genetic variation in small PCR amplicons (usually $80-120$ bp) by detecting small differences in the melting temperatures of the sequences through the melting curves (Wittwer 2009; Wittwer et al. 2003). Furthermore, this method is cheaper and faster than Sanger sequencing, being a good alternative to be used by many laboratories (Wittwer 2009). However, the scarcity or unavailability of HRM instruments can be a limitation of the technique. Although routinely qPCR instruments are designed to monitor fluorescence during DNA melting, not all allow performing the HRM analysis (Li et al. 2012). Also, the designed primers needs to follow some requirements to be successful, for example, amplification of short fragments, what can 
82 not be distinguished by HRM, as there is a better differentiation between $\mathrm{C} / \mathrm{T}$ and G/A or C/A

83 and $\mathrm{G} / \mathrm{T}$ than $\mathrm{C} / \mathrm{G}$ or $\mathrm{A} / \mathrm{T}$ (Roche Diagnostics GmbH 2012; Słomka et al. 2017).

84 HRM is being used to identify a wide range of organisms such as animals (Klomtong et al.

85 2016), plants (Mishra et al. 2018; Sun et al. 2016), fungi (Bezdicek et al. 2016), bacteria

86 (Iacumin et al. 2015), and protozoa (Aghaei et al. 2014). In the specific case of insects, it was

87 reported to identify forensic flies (Malewski et al. 2010) and mosquitos (Kang \& Sim 2013).

88 However, the insect species addressed in each study are specific to each region of the planet.

89 Thus, in this study, we reported a new HRM primer set to identify forensically important

90 Calliphoridae (blowflies) in Brazil.

91

\section{MATERIAL AND METHODS}

2.1. HRM Primer design

Initially, Calliphoridae species forensically important in Brazil were listed based on literature and checked by specialists. Mitochondrial COI barcode sequences of those species were downloaded from BOLD Systems (available at www.boldsystems.org) (Ratnasingham \& Hebert 2007) (examples are shown in Supplemental File S2) and aligned through ClustalW in Bioedit software (Hall 1999). Two regions containing polymorphic variations were selected 100 for species distinction (Supplemental File S3). HRM primers were designed using Primer3 101 software (http://bioinfo.ut.ee/primer3/) (Koressaar \& Remm 2007), flanking these regions and 102 generating small amplicon sizes, as shown in Table 1. uMelt Melting Curve Predictions 
104 predict the melting temperature of each amplicon, enabling identifying each species based on

105 its temperature variation.

106

107 2.2. Sample and DNA isolation

108 For this study, forty-three fly samples were used to validate the HRM assay. These samples 109 included six Calliphoridae species (Chrysomya albiceps (Wiedemann, 1819), Chrysomya 110 megacephala (Fabricius, 1794), Chrysomya putoria (Wiedemann, 1830), Cochliomyia 111 macellaria (Fabricius, 1775), Lucilia cuprina (Wiedemann, 1830), and Lucilia eximia

112 (Wiedemann, 1819)), collected from different sites in Southeast Brazil, and identified through 113 identification key (Carvalho \& Mello-Patiu 2008) and by the specialists Dr. Janyra Oliveira114 Costa (Rio de Janeiro Scientific Police) and Dr. Patrícia Jacqueline Thyssen (Unicamp/São 115 Paulo), as shown in the Supplemental File S1. Part of the samples had, approximately, eleven 116 years of collection and was sent to us in dry conditions, another part had six years and was 117 preserved in alcohol $70^{\circ} \mathrm{G} . \mathrm{L}$ and five fresh specimens of L. cuprina were supplied in absolute 118 alcohol. Genomic DNA was isolated from $20 \mathrm{mg}$ of thoracic muscles using NucleoSpin ${ }^{\circledR}$ 119 Tissue Kit (Macherey-Nagel, Germany) according to the manufacturer's instructions. DNA 120 concentration and purity were evaluated using a NanoDrop ${ }^{\mathrm{TM}} 2000$ Spectrophotometer 121 (Thermo Scientific, USA). DNA samples were stored at $-30{ }^{\circ} \mathrm{C}$ for further use.

2.3. PCR-HRM assay and data analysis

124 HRM with pre-amplification were performed on a LightCycler ${ }^{\circledR} 96$ real-time PCR instrument 125 (Roche Diagnostics). The HRM-PCR reaction mixture $(10 \mu \mathrm{L})$ contained $5 \mathrm{ng}$ of genomic 126 DNA, $5 \mu \mathrm{L}$ of SsoFast ${ }^{\mathrm{TM}}$ EvaGreen ${ }^{\circledR}$ Supermix, $500 \mathrm{nM}$ of each primer and ultrapure water 
127 up to the final volume. The samples were run in triplicate and a negative control was used in

128 each experiment to exclude contamination. DNA amplification was achieved under the

129 following conditions: first denaturation at $95^{\circ} \mathrm{C}$ for $2 \mathrm{~min}$, then 40 cycles of $95^{\circ} \mathrm{C}$ for $30 \mathrm{~s}$,

130 annealing at 54 and $56^{\circ} \mathrm{C}$, for 82 and $124 \mathrm{bp}$ amplicon, respectively, for $30 \mathrm{~s}$ and extension at

$13172{ }^{\circ} \mathrm{C}$ for $30 \mathrm{~s}$. After amplification, PCR products were denatured at $95{ }^{\circ} \mathrm{C}$ for 1 min and

132 renatured at $40{ }^{\circ} \mathrm{C}$ to form DNA duplexes. Melting curves were acquired by heating from 65

133 to $97^{\circ} \mathrm{C}$ with 25 data acquisitions per degree. Data were analyzed using LightCycler ${ }^{\circledR} 96 \mathrm{SW} 1.1$

134 version (Roche Diagnostics). Genotypes were identified by examining normalized melting

135 curves, difference and derivative plots of the melting data. Melting temperature (Tm) data were

136 statistically analyzed using Microsoft Excel 2010 and R statistical computing software (Team

137 2018) to the calculation of mean, standard deviation and confidence interval for each sample run

138 in triplicate (Supplemental File S4).

139 2.4. DNA sequencing

140 Samples were previously sequenced to validate the results of HRM analysis. For this purpose,

141 all samples were subjected to conventional PCR using universal COI primers. Table 1 shows

142 an alternative primer pair to produce short fragment $(385 \mathrm{bp})$ was used when universal primers

143 failed. PCR products were purified using ExoSAP protocol. Sequencing was performed on an

144 ABI 3500 DNA Sequencer (Thermo Fischer Scientific, USA) using BigDye Terminator Cycle

145 Sequencing Kit version 3.1 (Thermo Fischer Scientific, USA) following the manufacturer's

146 instructions. Sequences obtained were confronted with BOLD Systems

147 (http://www.boldsystems.org) and GenBank to identify species. Similarity above 99\% was 148 considered identified. 


\section{RESULTS AND DISCUSSION}

150 Identifying the six species proposed using two HRM amplicons was possible. Initially, an

151 amplicon with 82 bp was used and the species L. eximia, L. cuprina, C. putoria, and Co.

152 macellaria were distinguished, but C. megacephala and C. albiceps presented the same melting

153 curves, as shown in Fig. 1. Complementarily, a second amplicon with 124 bp was used and it

154 easily distinguished C. megacephala, Co. macellaria, C. albiceps, and C. putoria. The species $L$.

155 cuprina and L. eximia could not be distinguished due to the similarity of their melting curves

156 (Fig. 2). The second amplicon $124 \mathrm{bp}$ allowed identifying the species that $82 \mathrm{bp}$ amplicon could

157 not differentiate (Fig. 3).

158 The distinction of L. cuprina and L. eximia species by the 82 bp HRM amplicon was

159 advantageous since most samples of $L$. eximia could not be amplified and sequenced using

160 universal COI primers (658 bp fragment), only when we used a short fragment (385 bp). This

161 fact led us to believe that L. eximia samples would be degraded ( 5 of 6 samples were in a dry

162 state). Table 2 shows that the only L. eximia sample that could be identified by DNA sequencing

163 was the one preserved in alcohol, which suggests DNA was probably degraded in those samples.

164 DNA degradation could also explain why amplifying most of the old samples with the universal

165 DNA barcoding primers was not possible (Hajibabaei et al. 2006). It also occured for old

166 samples of C. albiceps and C. putoria. The amplification of large fragments does not occur when

167 the DNA is broken in smaller fragments, but a shorter marker can be used for identification

168 (Boyer et al. 2012).

169 Our results confirmed the efficiency of alcohol $70^{\circ} \mathrm{G} . \mathrm{L}$ in the preservation of samples. The

170 preservation in alcohol allowed the generation of DNA barcodes using the largest universal

171 primers for $100 \%$ of the samples, even for old samples. This confirms that the use of this solvent 
172 can be an important ally in long-term conservation of flies, improving the sequence recovery

173 rates (Elías-Gutiérrez et al. 2018). Similar results were also reported for other insects (Stein et al. 174 2013).

175 HRM was superior to DNA sequencing for dried (and possibly degraded) samples when the 176 storage condition was considered, since each sample was amplified using the universal primers. 177 The result was superior using $82 \mathrm{bp}$ and similar using $124 \mathrm{bp}$ amplicon in all of these samples, 178 including the fresh samples and the samples preserved in alcohol. Thus, dry or degraded samples 179 could be assayed with confidence by HRM.

180 The $82 \mathrm{bp}$ amplicon showed to be effective for the molecular analysis of old specimens DNA 181 with $92 \%$ of sample identification when the storage time was considered, while 124 bp amplicon 182 identified only $68 \%$. This 82 bp amplicon presented $92 \%$ of sample identification against $66 \%$ 183 when compared with DNA sequencing. We only used specimens with more than a decade and 184 degraded DNA to show HRM analysis is sufficient to distinguish species in difficult conditions.

185 Although DNA sequencing has been considered the best technique for species identification, it 186 could not be efficient at identifying degraded samples amplifying large fragments. Moreover, 187 this procedure is laborious and expensive. The HRM technique overcomes these problems since 188 it can amplify and distinguish even species with degraded DNA (Boyer et al. 2012). This is a 189 closed tube technique, reducing the contamination risks without using toxic reagents. In addition, 190 the working time is short; sample analysis, detection of DNA polymorphisms, and distinctions 191 between the melting curves can last about 2 hours. Furthermore, HRM technique is cheaper than 192 sequencing. Thus, adopting the HRM technique in laboratory routine and genetic studies is 193 possible. 


\section{CONCLUSIONS}

196

197

198

199

200

201

202

203

204

205

206

207

208

209

210

211

212

213

214

215

216

Our results support that the HRM analysis using our COI primer set is a powerful tool and sensitive technique for the identification and distinction of occurring Calliphoridae species in Brazil. The two amplicons designed can be reliably used to determine species identity, especially when morphological identification is not possible. Moreover, even ancient specimens collected and preserved dried for more than ten years, with possible degraded DNA, could be identified, unlike what occurs when using the DNA sequencing technique, which failed for those samples. New HRM assays should be performed in other blowfly forensic groups to facilitate the routine identification of species.

\section{ACKNOWLEDGEMENTS}

We thank Dr. Patrícia Jacqueline Thyssen for providing us with the samples used in this study, Dr. Márcia Flores da Silva Ferreira for the authorization to use the real time PCR equipment. We also thank the Graduate Program in Biotechnology of the Federal University of Espirito Santo, and group research, Geotechnology Applied to Global Environment (GAGEN).

\section{REFERENCES}

Aghaei, A. A., Rassi, Y., Sharifi, I., ... Rafizadeh, S. (2014). First report on natural Leishmania infection of Phlebotomus sergenti due Leishmania tropica by high resolution melting curve method in South-eastern Iran. Asian Pacific Journal of Tropical Medicine, 7(2), 93-96. 
217 Amendt, J., Krettek, R., \& Zehner, R. (2004). Forensic entomology. Naturwissenschaften, 91(2), $218 \quad 51-65$.

219 Amendt, J., Richards, C. S., Campobasso, C. P., Zehner, R., \& Hall, M. J. R. (2011). Forensic 220 entomology: applications and limitations. Forensic Science, Medicine, and Pathology, 7(4), $221 \quad 379-392$.

222

223

Bansal, S., Thakur, S., Mangal, M., Mangal, A. K., \& Gupta, R. (2018). DNA barcoding for specific and sensitive detection of Cuminum cyminum adulteration in Bunium persicum. Phytomedicine. doi:10.1016/j.phymed.2018.04.023

Bezdicek, M., Lengerova, M., Ricna, D., ... Racil, Z. (2016). Rapid detection of fungal pathogens in bronchoalveolar lavage samples using panfungal PCR combined with high resolution melting analysis. Medical Mycology. doi:10.1093/mmy/myw032

Boyer, S., Brown, S. D. J., Collins, R. A., ... Wratten, S. D. (2012). Sliding Window Analyses for Optimal Selection of Mini-Barcodes, and Application to 454-Pyrosequencing for Specimen Identification from Degraded DNA. PLoS ONE, 7(5), e38215.

Carvalho, C. J. B. de, \& Mello-Patiu, C. A. de. (2008). Key to the adults of the most common forensic species of Diptera in South America. Revista Brasileira de Entomologia, 52(3), $390-406$.

Castro, O. De, Comparone, M., Di Maio, A., ... Guida, M. (2017). What is in your cup of tea? DNA verity test to characterize black and green commercial teas. PLoS ONE, 12(5), 1-17.

Catts, E. P., \& Goff, M. L. (1992). Forensic Entomology in Criminal Investigations. Annual Review of Entomology, 37(1), 253-272. 
238 CBOL Plant Working Group, Hollingsworth, P. M., Forrest, L. L., ... Little, D. P. (2009). A

239 DNA barcode for land plants. Proceedings of the National Academy of Sciences of the

$240 \quad$ United States of America, 106(31), 12794-7.

241 Chen, W.-Y., Hung, T.-H., \& Shiao, S.-F. (2004). Molecular Identification of Forensically

242 Important Blow Fly Species (Diptera: Calliphoridae) in Taiwan. Journal of Medical

$243 \quad$ Entomology, 41(1), 47-57.

244 Cooke, T., Kulenkampff, K., Heyns, M., \& Heathfield, L. J. (2019). DNA barcoding of

245 forensically important flies in the Western Cape, South Africa. Genome, 61(12), 823-828.

246 David, J. A. de O., Rocha, T., \& Caetano, F. H. (2008). Ultramorphological characteristics of

247 Chrysomya megacephala (Diptera, Calliphoridae) eggs and its eclosion. Micron, 1134-

$248 \quad 1137$.

Dawnay, N., Hughes, R., Court, D. S., \& Duxbury, N. (2016). Species detection using HyBeacon probe technology: Working towards rapid onsite testing in non-human forensic and food authentication applications. Forensic Science International: Genetics, 20, 103-111.

252

253

254

255

256

257

258

Elías-Gutiérrez, M., Valdez-Moreno, M., Topan, J., Young, M. R., \& Cohuo-Colli, J. A. (2018). Improved protocols to accelerate the assembly of DNA barcode reference libraries for freshwater zooplankton. Ecology and Evolution, 8, 3002-3018.

Fernandes, T. J. R., Costa, J., Oliveira, M. B. P. P., \& Mafra, I. (2017). COI barcode-HRM as a novel approach for the discrimination of hake species. Fisheries Research, 197(April 2017), 50-59.

Folmer, O., Black, M., Hoeh, W., Lutz, R., \& Vrijenhoek, R. (1994). DNA primers for 
amplification of mitochondrial cytochrome c oxidase subunit I from diverse metazoan invertebrates. Molecular Marine Biology and Biotechnology, 3(5), 294-299.

261 Galan, M., Pagès, M., \& Cosson, J.-F. (2012). Next-Generation Sequencing for Rodent Barcoding: Species Identification from Fresh, Degraded and Environmental Samples. PLoS

GilArriortua, M., Saloña Bordas, M. I., Köhnemann, S., Pfeiffer, H., \& de Pancorbo, M. M. (2014). Molecular differentiation of Central European blowfly species (Diptera, ONE, 7(11), e48374.

Hajibabaei, M., Smith, M. A., Janzen, D. H., Rodriguez, J. J., Whitfield, J. B., \& Hebert, P. D. N. (2006). A minimalist barcode can identify a specimen whose DNA is degraded. Molecular Ecology Notes, 6, 959-964.

Hall, T. A. (1999). BioEdit: a user-friendly biological sequence alignment editor and analysis program for Windows 95/98/NT. Nucleic Acids Symposium Series, 41, 95-98.

Hebert, P. D. N., Cywinska, A., Ball, S. L., \& deWaard, J. R. (2003a). Biological identifications through DNA barcodes. Proceedings of the Royal Society B: Biological Sciences, 270(1512), 313-321.

276

277

278

279

Hebert, P. D. N., Ratnasingham, S., \& deWaard, J. R. (2003b). Barcoding animal life : cytochrome c oxidase subunit 1 divergences among closely related species Barcoding animal life : cytochrome c oxidase subunit 1 divergences among closely related species. Proc. R. Soc. Lond. B, 270, S96-S99. 
280 Iacumin, L., Ginaldi, F., Manzano, M., ... Comi, G. (2015). High resolution melting analysis 281 (HRM) as a new tool for the identification of species belonging to the Lactobacillus casei

282

283

284

285

286

287

288

289

290

291

292

293

294

295

296

297

298

299

300

Jang, H., Shin, S. E., Ko, K. S., \& Park, S. H. (2019). SNP Typing Using Multiplex Real-Time PCR Assay for Species Identification of Forensically Important Blowflies and Fleshflies Collected in South Korea (Diptera: Calliphoridae and Sarcophagidae). BioMed Research International. doi:10.1155/2019/6762517

Kang, D., \& Sim, C. (2013). Identification of Culex complex species using SNP markers based on high-resolution melting analysis. Molecular Ecology Resources, 13(3), 369-376.

Klippel, A. H., Oliveira, P. V., Britto, K. B., ... Paneto, G. G. (2015). Using DNA barcodes to identify road-killed animals in two atlantic forest nature reserves, Brazil. PLoS ONE, 10(8), $1-15$.

Klomtong, P., Phasuk, Y., \& Duangjinda, M. (2016). Animal Species Identification through High Resolution Melting Real Time PCR (HRM) of the Mitochondrial 16S RRNA Gene. Annals of Animal Science, 16(2), 415-424.

Koressaar, T., \& Remm, M. (2007). Enhancements and modifications of primer design program Primer3. Bioinformatics, 23(10), 1289-1291.

Kress, W. J., Wurdack, K. J., Zimmer, E. A., Weigt, L. A., \& Janzen, D. H. (2005). Use of DNA barcodes to identify flowering plants. Proceedings of the National Academy of Sciences. doi:10.1073/pnas.0503123102 
301

302

303

304

305

306

307

308

309

310

311

312

313

314

315

316

317

318

319

320

321

322

Li, F., Niu, B., Huang, Y., \& Meng, Z. (2012). Application of high-resolution DNA melting for genotyping in lepidopteran non-model species: Ostrinia furnacalis (crambidae). PLoS ONE, 7(1). doi:10.1371/journal.pone.0029664

Malewski, T., Draber-Mońko, A., Pomorski, J., Łoś, M., \& Bogdanowicz, W. (2010).

Identification of forensically important blowfly species (Diptera: Calliphoridae) by highresolution melting PCR analysis. International Journal of Legal Medicine, 124(4), 277-285.

Mendonça, P. M., Barbosa, R. R., Carriço, C., Cortinhas, L. B., Santos-Mallet, J. R. dos, \& Queiroz, M. M. de C. (2014a). Ultrastructure of immature stages of Lucilia cuprina (Diptera: Calliphoridae) using scanning electron microscopy. Acta Tropica, 136(1), 123128.

Mendonça, P. M., Barbosa, R. R., Cortinhas, L. B., dos Santos-Mallet, J. R., \& de Carvalho Queiroz, M. M. (2014b). Ultrastructure of immature stages of Cochliomyia macellaria (Diptera: Calliphoridae), a fly of medical and veterinary importance. Parasitology Research, 113(10), 3675-3683.

Mishra, P., Shukla, A. K., \& Sundaresan, V. (2018). Candidate DNA Barcode Tags Combined With High Resolution Melting (Bar-HRM) Curve Analysis for Authentication of Senna alexandrina Mill. With Validation in Crude Drugs. Frontiers in Plant Science, 9(283). doi:10.3389/fpls.2018.00283

Oliveira, P. V, Matos, N. S., Klippel, A. H., Oliveira-Costa, J., Careta, F. P., \& Paneto, G. G. (2017). Using DNA barcodes to identify forensically important species of Diptera in Espírito Santo state, Brazil. Brazilian Archives of Biology and Technology, 60(e160106), 1- 
323 Osathanunkul, M., Osathanunkul, R., \& Madesis, P. (2018). Species identification approach for

324 both raw materials and end products of herbal supplements from Tinospora species. BMC Complementary and Alternative Medicine, 18(111). doi:10.1186/s12906-018-2174-0

326

327

Ratnasingham, S., \& Hebert, P. D. N. (2007). BOLD: The Barcode of Life Data System (www.barcodinglife.org). Molecular Ecology Notes, 7, 355-364.

Roche Diagnostics GmbH. (2012). LightCycler® 96 System Guides.

Rolo, E. A., Oliveira, A. R., Dourado, C. G., Farinha, A., Rebelo, M. T., \& Dias, D. (2013). Identification of sarcosaprophagous Diptera species through DNA barcoding in wildlife forensics. Forensic Science International, 228, 160-164.

Schoch, C. L., Seifert, K. A., Huhndorf, S., ... Consortium, F. B. (2012). Nuclear ribosomal internal transcribed spacer (ITS) region as a universal DNA barcode marker for Fungi. Proceedings of the National Academy of Sciences, 109(16), 6241-6246.

Słomka, M., Sobalska-Kwapis, M., Wachulec, M., Bartosz, G., \& Strapagiel, D. (2017). High resolution melting (HRM) for high-throughput genotyping-limitations and caveats in practical case studies. International Journal of Molecular Sciences, 18(11). doi:10.3390/ijms18112316

Sontigun, N., Sukontason, K., Amendt, J., ... Wannasan, A. (2018). Molecular Analysis of Forensically Important Blow Flies in Thailand. Insects, 9(159). doi:10.3390/insects9040159

Sontigun, N., Sanit, S., Wannasan, A., ... Sukontason, K. L. (2018). Ultrastructure of male genitalia of blow flies (Diptera: Calliphoridae) of forensic importance. Acta Tropica, 179, $61-80$. 
344 Stein, E. D., White, B. P., Mazor, R. D., Miller, P. E., \& Pilgrim, E. M. (2013). Evaluating

345 Ethanol-based Sample Preservation to Facilitate Use of DNA Barcoding in Routine

346 Freshwater Biomonitoring Programs Using Benthic Macroinvertebrates. PLoS ONE.

347 doi:10.1371/journal.pone.0051273

348 Sun, W., Li, J., Xiong, C., Zhao, B., \& Chen, S. (2016). The Potential Power of Bar-HRM

349 Technology in Herbal Medicine Identification. Frontiers in Plant Science, 7(367), 1-10.

350 Team, R. C. (2018). A Language and Environment for Statistical Computing. R Foundation for

$351 \quad$ Statistical Computing, p. https://www.R-project.org.

352 Wells, J. D., \& Sperling, F. A. H. (2001). DNA-based identification of forensically important

353 Chrysomyinae (Diptera: Calliphoridae). Forensic Science International, 120(1-2), 110-

$354 \quad 115$.

355

356

357

358

359

360

361

362

Wittwer, C. T. (2009). High-resolution DNA melting analysis: advancements and limitations. Human Mutation, 30(6), 857-859.

Wittwer, C. T., Reed, G., Gundry, C. N., Vandersteen, J. G., \& Pryor, R. J. (2003). Highresolution genotyping by amplicons melting analysis using LCGreen. Clinical Chemistry, 49, 853-860.

Zajac, B. K., Sontigun, N., Wannasan, A., ... Zehner, R. (2016). Application of DNA barcoding for identifying forensically relevant Diptera from northern Thailand. Parasitology Research, 115(6), 2307-2320. 
Figure 1

High-Resolution Melting analysis using COI primers (82 pb amplicon) for identification of Calliphoridae (blowflies) species.

(a) Normalized melting curves. (b) Difference plot curves using C. megacephala as reference genotype. Orange: L. eximia; Blue: L. cuprina; Black: C. megacephala and C. albiceps; Red: Co. macellaria; Green: C. putoria.
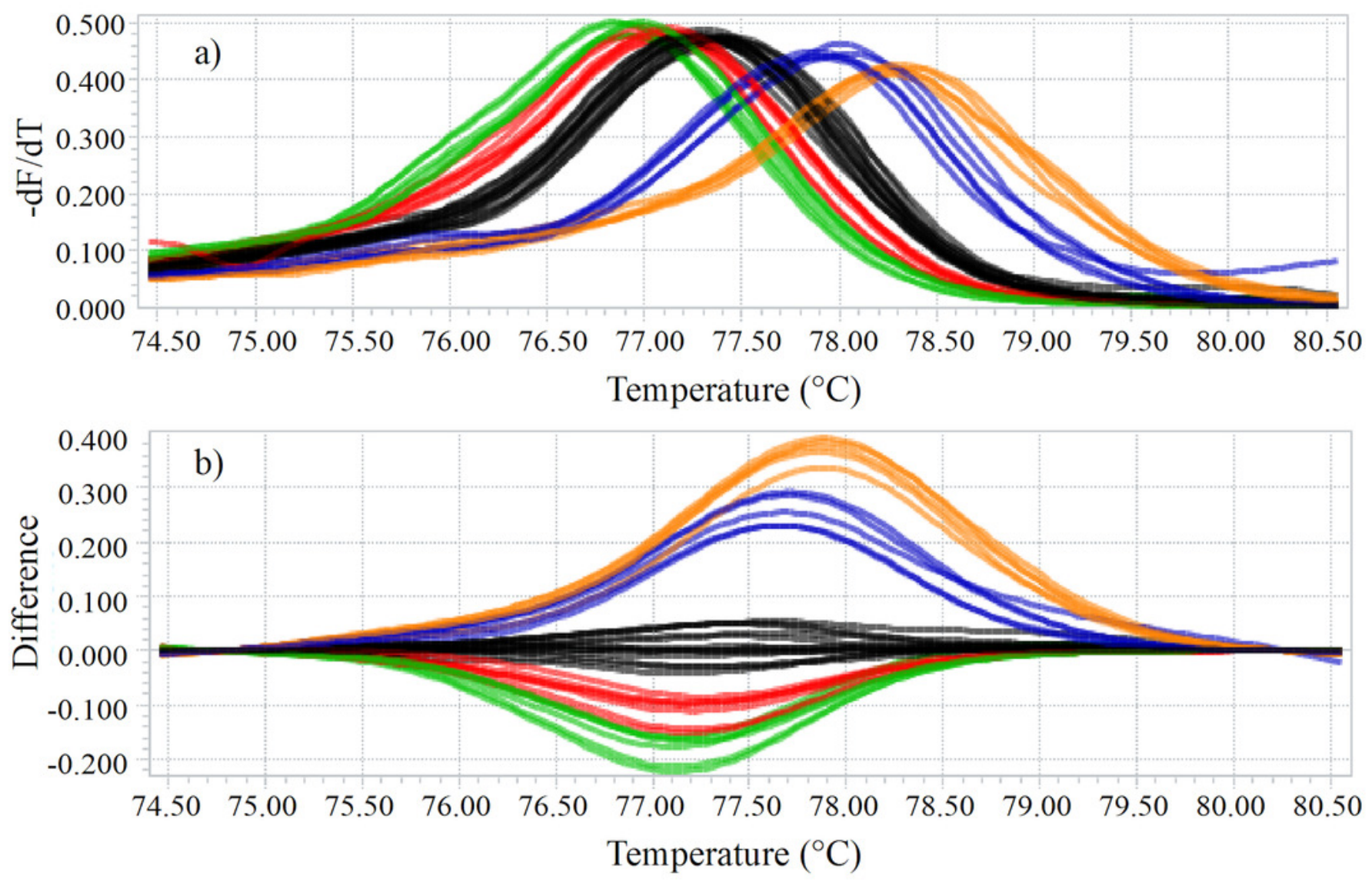
Figure 2

High-Resolution Melting analysis using COI primers (124 pb amplicon) for forensic species.

(a) Normalized melting curves. (b) Difference plot curves using C. albiceps as reference genotype. Yellow: C. megacephala; Red: Co. macellaria; Brown: C. albiceps; Black: L. cuprina and L. eximia; Green: C. putoria.
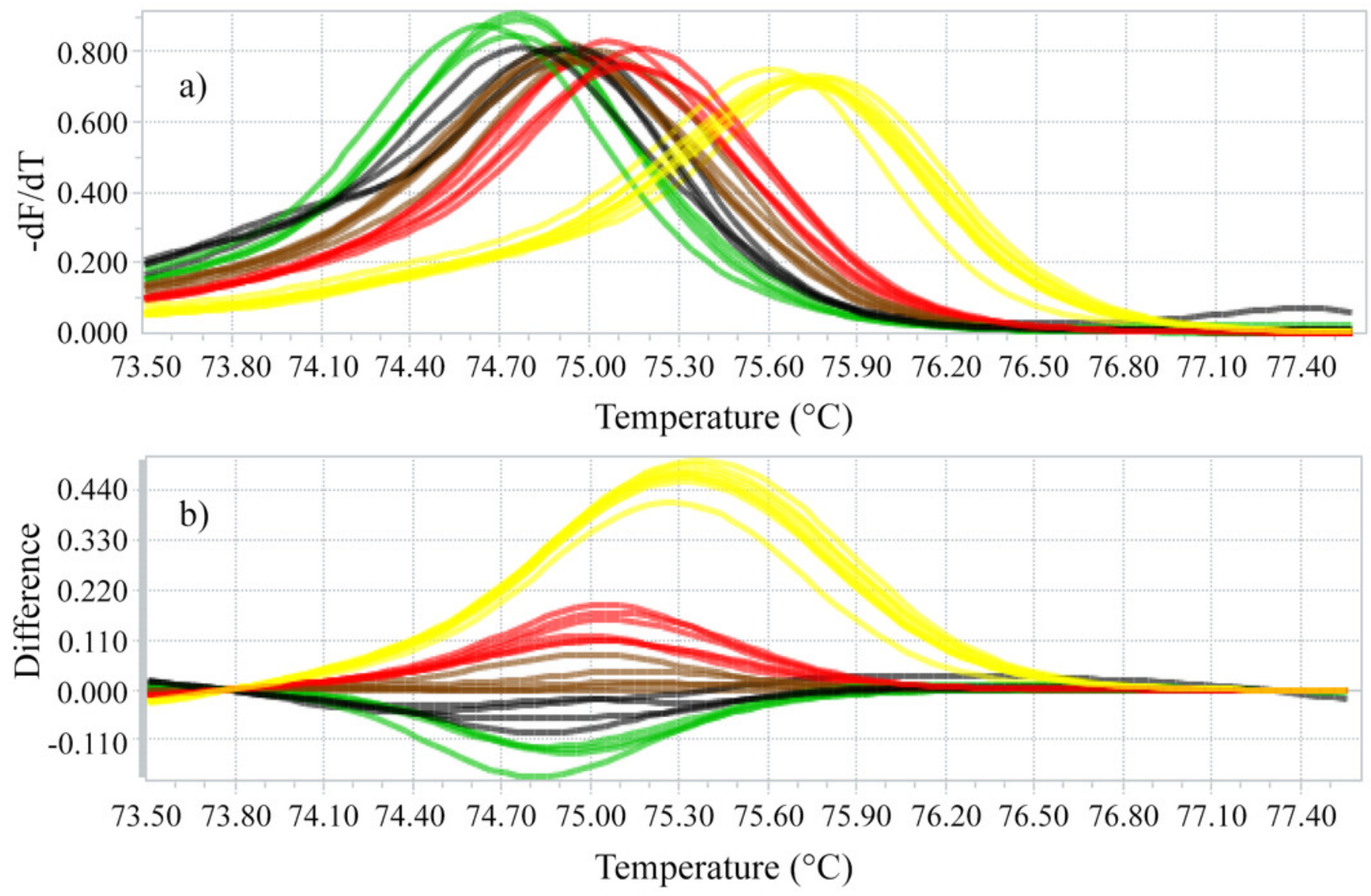
Figure 3

Flowchart showing species identification of blowflies using each of the HRM primers proposed, A) 82 bp amplicon and B) 124 bp amplicon.

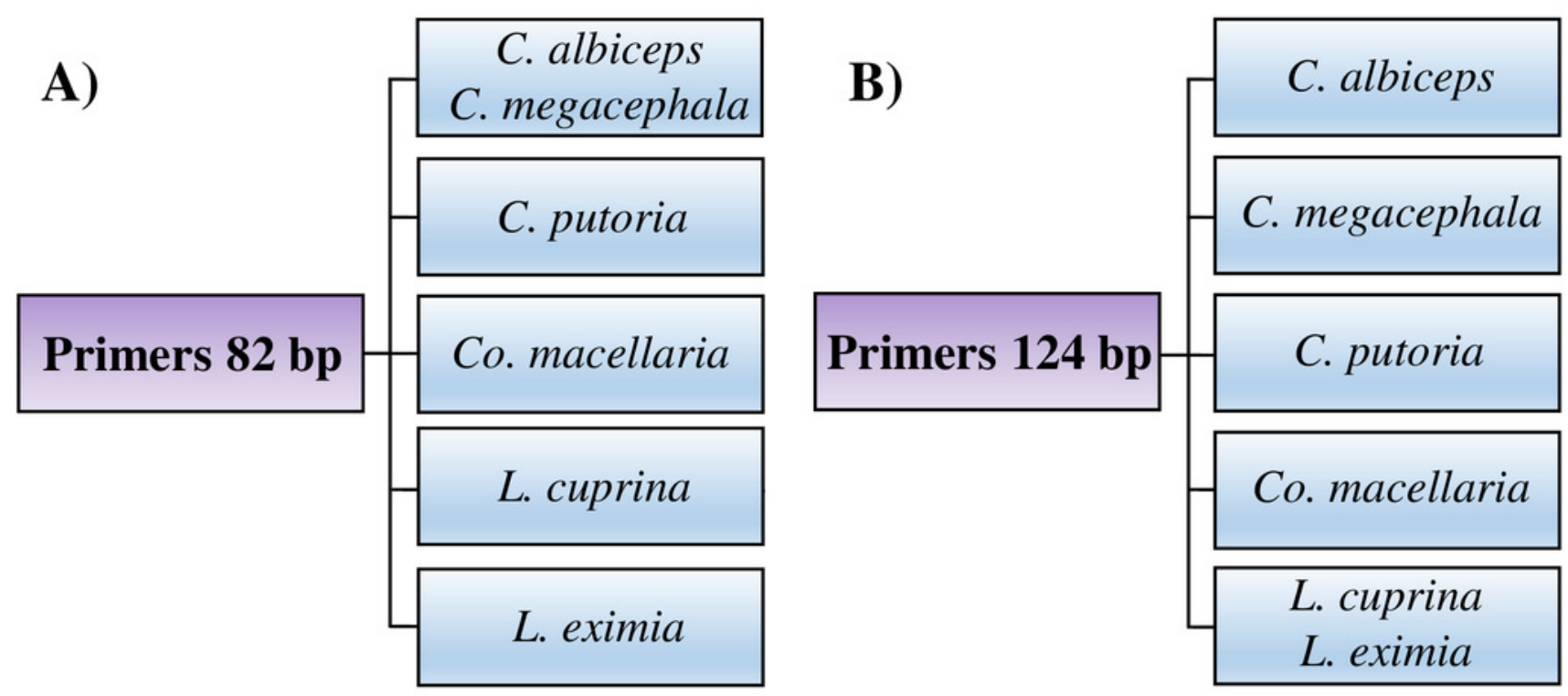




\section{Table $\mathbf{1}$ (on next page)}

Primer sequences used in this study 
1 Table 1. Primer sequences used in this study.

\begin{tabular}{|c|c|c|c|c|c|}
\hline Name & Direction & $\begin{array}{c}\text { Sequence } \\
\left(5^{\prime} \rightarrow 3 \text { ') }\right.\end{array}$ & $\begin{array}{c}T a \\
\left({ }^{\circ} \mathrm{C}\right)\end{array}$ & $\begin{array}{c}\text { Amplicon } \\
\text { size (bp) }\end{array}$ & Source \\
\hline HRM_82F & Forward & AGTAGAAAATGGGGCTGGAA & \multirow{2}{*}{54} & \multirow{2}{*}{82} & This study \\
\hline HRM $82 \mathrm{R}$ & Reverse & АTCAACTGATGCTCCTCCAT & & & \multirow{3}{*}{ This study } \\
\hline HRM_124F & Forward & AATGTAATTGTAACAGCTCACG & \multirow{2}{*}{56} & \multirow{2}{*}{124} & \\
\hline HRM_124R & Reverse & GTGGGAAAGCTATATCTGGAG & & & \\
\hline LCO-1490 & Forward & GGTCAACAAATCATAAAGATATTGG & \multirow{2}{*}{51} & \multirow{2}{*}{658} & \multirow{2}{*}{ (Folmer et al. 1994) } \\
\hline HCO-1490 & Reverse & TAAACTTCAGGGTGACCAAAAAAT & & & \\
\hline C1-J-2495 & Forward & CAGCTACTTTATGAGCTTTAGG & \multirow{2}{*}{51} & \multirow{2}{*}{304} & (Wells and Sperling \\
\hline $\mathrm{C} 1-\mathrm{N}-2800$ & Reverse & CATTTCAAGCTGTGTAAGCATC & & & 2001) \\
\hline
\end{tabular}




\section{Table 2 (on next page)}

Percentage of samples with results using DNA sequencing and High-Resolution Melting when preservation condition and time since collection were analyzed 
1 Table 2. Percentage of samples with results using DNA sequencing and High-Resolution

2 Melting when preservation condition and time since collection were analyzed.

\begin{tabular}{|c|c|c|c|c|c|}
\hline Condition & $\begin{array}{c}\text { Number of } \\
\text { samples }\end{array}$ & $\begin{array}{c}650 b p \\
\text { fragment } \\
(\%) \\
\end{array}$ & $\begin{array}{c}300 b p \\
\text { fragment } \\
(\%) \\
\end{array}$ & $\begin{array}{c}\text { HRM } \\
82 \text { bp } \\
(\%) \\
\end{array}$ & $\begin{array}{c}\text { HRM } \\
124 \mathrm{bp} \\
(\%)\end{array}$ \\
\hline Dry & 13 & 0 & 100 & 92 & 46 \\
\hline Alcohol & 25 & 100 & $*$ & 92 & 80 \\
\hline Fresh & 5 & 100 & $*$ & 100 & 40 \\
\hline Total & 43 & 68 & 30 & 91 & 65 \\
\hline Condition & $\begin{array}{l}\text { Number of } \\
\text { samples }\end{array}$ & $\begin{array}{c}\text { 650bp fragment } \\
(\%)\end{array}$ & $\begin{array}{c}\text { 300bp fragment } \\
(\%)\end{array}$ & $\begin{array}{c}\text { HRM } \\
82 \text { bp } \\
(\%) \\
\end{array}$ & $\begin{array}{c}\text { HRM } \\
124 \text { bp } \\
(\%) \\
\end{array}$ \\
\hline Ancient & 38 & 66 & $*$ & 92 & 68 \\
\hline Fresh & 5 & 100 & $*$ & 100 & 40 \\
\hline Total & 43 & 70 & 30 & 91 & 65 \\
\hline
\end{tabular}

3 Note: *Samples sequenced only using 658 bp amplicon.

4 